Prof. dr. Refik Ćatic ${ }^{1}$ i Samira Karajbić, prof.

\title{
DOPISNA SARADNJA PORODICE I ŠKOLE
}

\section{SAŽETAK}

U radu se govori o osobenosti i ulozi porodice i škole kao dvaju ključnih faktora u odgojno-obrazovnome radu.

Cilj istraživanja je istražiti i interpretirati zastupljenost $i$ kvalitet dopisne saradnje porodice $i$ škole $u$ našim osnovnim školama, uporediti dopisnu saradnju u našim školama s primjerima dopisne saradnje iz Njemačke $i$ Italije, kako bi se ta saradnja mogla unaprijediti.

U istraživanju, kao osnovni metoda, korištena je empirijskoneeksperimentalna (servej metoda) i rad na dokumentaciji. Glavni instrument u ovome istraživanju je upitnik nastavnika. Istraživanje je vršeno u dvije osnovne škole u Zavidovićima. Uzorak je bio 40 nastavnika.

Izdvaja se jasan zaključak, da kod nas, u poređenju sa svjetskim iskustvima, nisu iskorištene sve mogućnosti koje nudi dopisna saradnja.

Ključne riječi: dopisna saradnja, razrednik, roditelji, škola, školska dokumentacija.

\section{Uvod}

Danas je najaktuelnija tema saradnje porodice i škole $u$ pedagoškoj praksi. Budući da su škole u većini društava središnje društvene institucije, one su u takvome položaju da stvaraju partnersku mrežu sa svim pojedincima, grupama, organizacijama i institucijama koje dijele odgovornost za napredak i razvoj učenika.

Školama su potrebni prijatelji - kritičari, pojedinci i grupe, koje im $u$ potrebnom trenutku slušaju i pomažu da postave smjernice $i$ donesu zdrave odluke.

\footnotetext{
${ }^{1}$ Pedagoški fakultet u Zenici
} 
Dosadašnja praksa je pokazala nedostatak saradnje roditelja i škole, jer se ona uglavnom provodi preko roditeljskih $\mathrm{i}$ informativnih sastanaka. Roditelji u školu najčešće dolaze da vide ocjene svoga djeteta, a o ostalim segmentima života škole znaju veoma malo.

Porodicu i školu bismo trebali posmatrati kao neodvojivu cjelinu. Jedna bez druge, teško da će uspjeti uputiti dijete na pravi put i naučiti ga šta su to prave vrijednosti. Možda je to upravo razlog što su današnja djeca sve više bez pozitivnih ideala u životu, bez ciljeva, a sve više i sa manjkom poštovanja prema sebi i drugima.

\section{Terminološka i fenomenološka analiza}

Pojam saradnje porodice $\mathrm{i}$ škole nije nov. Ranije se taj pojam uzimao jednostrano, škola je sarađivala $\mathrm{s}$ tankim slojem bolje situiranih roditelja u gradovima. Saradnja se veoma malo provodila na selu, jer su seljačke mase bile nepismene, i uglavnom se nisu interesovale za školu i prosvjetne probleme.

U životu djeteta, porodica i škola, jesu dva najvažnija odgojna faktora, koja se i susreću kroz odnose prema djetetu i na taj način kreiraju novi sistem koji ima sopstvene karakteristike i osobenu dinamiku odnosa, što je dijelom moguće sagledati združivanjem gledišta različitih učesnika sistema.

Porodica je temelj djetetovog rasta i razvoja. U njoj dijete stiče znanja, uči vještine, razvija navike i sposobnosti, stiče osnovna karakterna svojstva, osnovne radne, higijenske, estetske i moralne norme - kulturu mladih. Porodični život predstavlja osnovnu bazu za razvoj fizičkog i mentalnog zdravlja ličnosti, razvoj modela društvenog ponašanja i djelovanja u društvu.

Mnogobrojni mislioci su isticali bitnu ulogu porodice u odgoju djece, a današnja pedagogija posebno ističe i naglašava njenu nezamjenljivu ulogu. Značaj i uloga porodice u odgoju proizlazi iz nekoliko činjenica:

- Iz same prirode porodičnog kolektiva, iz bliske, tople i srdačne povezanosti njenih članova;

- Iz toga što djeca u porodici provode najveći dio svoga vremena; 
- Iz toga što su djeca u mlađim godinama, a naročito do polaska u školu, najpodložnija odgojnome utjecaju, stiču se prvi elementi znanja i ponašanja, te udaraju temelji najvažnijih osobina ličnosti.

Porodica, prema Ekermanu, osigurava fizički opstanak i razvija osnovne ljudske osobine čovjeka. Za ovog naučnika, osnovne funkcije porodice su:

- Zadovoljavanje materijalnih potreba članova u uvjetima društvenog jedinstva $i$ saradnje;

- Stvaranje uvjeta za zadovoljavanje emocionalnih potreba;

- Razvijanje ličnoga identiteta svakoga člana vezanog za identitet porodice;

- Podsticanje učenja $i$ podrška individualnoj kreativnosti $i$ inicijativi;

- Oblikovanje seksualnih uloga;

- Pripremanje za integriranje s društvenim ulogama i prihvatanje društvene odgovornosti. (Ćatić 1997: 11)

Škola je institucija u kojoj mlada ličnost počinje dobivati prva cjelovitija $i$ sistematičnija znanja, sposobnosti $i$ navike iz općeg fundusa ljudske civilizacije. (Ajanović - Stevanović 1998: 107)

U prvim godinama školovanja najveći odgojni utjecaj ima učitelj, a poslije sve veću ulogu imaju vršnjaci. Roditelji ni jednoga trenutka ne bi smjeli smetnuti s uma kako je rad u školi samo dio životne bujice u kojoj dijete mora plivati. (Hitrec 1991: 81)

Škola je najpoznatija, najznačajnija, najstarija, najmasovnija i najrazvijenija odgojno-obrazovna ustanova. Ona ima sljedeće funkcije:

- Pedagošku funkciju: podrazumijeva proces učenja djece $u$ razvoju;

- Društvenu funkciju: društveno uvjetovan okvir, programski određeni ciljevi i zadaci.

Pored ovih, škola ima i druge funkcije kao što su: socijalizacija djece, kvalifikacija za određeno zanimanje, navikavanje na predan rad, 
pružanje sigurnoga boravka dok se u njoj boravi, davanje doprinosa za osamostaljivanje djeteta, sticanje navika pravilnoga ponašanja i sl.

Termin partnerstvo podrazumijeva ravnopravnost partnera $\mathrm{u}$ odgojno-obrazovnome radu. U radnome okruženju škole postoji veći broj zainteresiranih grupa koje imaju određeni pozitivni ili negativni utjecaj na rad škole, ili na koje škola svojim radom utječe. Jedna od tih grupa su roditelji učenika škole. Roditelji su brojna, heterogena i međusobno slabo povezana grupa. Njihov je osnovni zajednički interes krajnji ishod školovanja njihove djece - školski uspjeh ili postignuće, izraženo kroz ocjene.

\section{Potrebe za saradnju porodice i škole}

U našoj zemlji svaka škola svojim godišnjim programom rada predviđa saradnju s roditeljima, ali se u praksi to svodi na povremenu komunikaciju iniciranu od strane direktora ili nastavnika. Najčešće se od roditelja traži, da podrže određene aktivnosti koje je škola već osmislila, a izuzetne su prilike kada roditelji učestvuju u planiranju i kreiranju sadržaja važnih za odgojno-obrazovni rad, ili kad su djelomično uključeni u njihovu realizaciju.

Zakonski date mogućnosti, kao što je Vijeće roditelja, često se vrlo formalno primjenjuju. U procesu demokratizacije, neophodno je razvijati relaciju škola - roditelji u pravcu otvorenosti, kontinuirane dvosmjerne komunikacije, povjerenja i jednakoga međusobnog uvažavanja.

S obzirom na organizacione kapacitete kojima raspolaže, škola ima inicijalnu odgovornost za partnersku relaciju s roditeljima i za dostignuti kvalitet relacije.

Pored škole kao institucije, jedan od najbitnijih faktora za ostvarivanje uspješne saradnje, jeste nastavnik, njegova želja, motiviranost i spremnost za saradnju.

Inicijative nastavnika će biti uspješno prihvaćene ako isti posjeduje sljedeće osobine:

- Da pokazuje svoju dobronamjernost;

- Da je spreman sačuvati ukazano povjerenje; 
- Da s odgovornošću obavlja svoj posao;

- Da se korektno se odnosi prema ljudima;

- Da pokazuje interes za probleme drugih, spremnost da im pomogne i sl.

Partnerstvo teži da ostvari ciljeve koji su prvenstveno u interesu djeteta i koje dijete može dostići i ostvariti.

U predstojećem reformiranom obrazovanju, humanistički i demokratski odnos roditelj - škola treba biti sljedeći :

- Roditelji su značajan partner škole;

- Stvaranje škole usmjerene ka razvoju djeteta;

- Adekvatno informiranje roditelja o radu škole i mogućnostima kako da pomognu svome djetetu pri učenju kod kuće;

- Usklađivanje mjera porodičnog odgoja s mjerama škole;

- Roditelji kao moralna podrška djeci u školi;

- Roditelji participiraju kao partneri u utvrđivanju ciljeva škole, razvoja i evaluacije programa i politike;

- Edukacija (roditelji kao punopravni partneri);

- Učešće roditelja kao ravnopravnih partnera u jačanju porodice $\mathrm{i}$ škole;

- Formiranje Vijeća roditelja;

- Proširivanje roditeljskih aktivnosti na nivou lokalne zajednice, općine;

- Davanje podrške roditeljima i učenicima koji su socijalno ugroženi, ili koji imaju teškoće u razvoju;

- Davanje podrške talentiranijim učenicima;

- Uključivanje roditelja u vannastavne aktivnosti - kreiranje slobodnog vremena.

Od znalački organizirane i pedagoški jasno usmjerene saradnje porodice i škole, u mnogome zavisi potpunije shvatanje i praktično ostvarivanje osnovnih ciljeva odgoja. 
Model partnerstva porodice i škole stavlja učenika u centar interesovanja. Saradnja omogućuje, da se uvijek zna šta i kako učenik radi, kada i zašto mu je potrebna pomoć i dokle dosežu rezultati njegovoga rada. Prema tome, proturječnosti između porodice i škole ne smije biti.

Porodica i škola moraju odgajati djecu u jedinstvenom pravcu i moraju se međusobno pomagati. Škola mora shvatiti važnost roditeljske saradnje u odgojno-obrazovnome procesu i pridobiti roditelje za saradnju. Moramo biti svjesni, kako će rezultati odgojnoobrazovnoga rada biti potpuni tek onda ako i porodica bude prožeta istom odgojnom mišlju kao i škola, ako domaći odgoj pomogne odgojne ciljeve škole.

S druge strane, važna društvena funkcija porodice doći će do punoga izražaja tek onda kada ona dadne svoj puni doprinos u odgoju mladoga naraštaja. Karakteristike odnosa roditelja i nastavnika, predstavljaju bitan elemenat od koga direktno zavisi kvalitet, efikasnost i racionalnost saradnje.

Razlikuju se dva suprotna shvatanja odnosa roditelja i nastavnika u procesu saradnje:

1. Roditelji i nastavnici nemaju ravnopravan položaj u procesu saradnje; nastavnici znaju više i bolje od roditelja koji svoju roditeljsku funkciju obavljaju bez ikakvoga potrebnog stručnog osposobljavanja. Posljedice ovakvih shvatanja su:

- Povlašten položaj nastavnika;

- Uspostavljene veze su jednosmjerne;

- Roditelji su u položaju posebnoga posmatrača;

- Postoji čitav niz normi i pravila čije poštovanje treba osigurati autoritaran odnos nastavnika prema roditelju;

- Kao posljedica toga njihov odnos karakterizira mnogo nesporazuma, optuživanja i prebacivanja.

2. Nastavnici i roditelji su ravnopravni učesnici u procesu saradnje; nastavnik nema povlašten položaj; komunikacija se zasniva na što objektivnijem sagledavanju potreba i mogućnosti učesnika u 
komunikaciji. U procesu saradnje roditelji su aktivni učesnici, odnosi su spontani i srdačni.

Za razvijanje dobrih odnosa između roditelja i nastavnika u procesu saradnje važno je:

- Dobro međusobno poznavanje roditelja i nastavnika;

- Neophodno je stalno podsticati i razvijati pozitivne stavove nastavnika prema roditeljima i obrnuto;

- Odnosi trebaju biti, kroz sve faze kroz koje saradnja prolazi, ravnopravni;

- Odnosi se trebaju temeljiti na međusobnom povjerenju i poštenju;

- Empatija treba biti osnova za njihovo međusobno razumijevanje;

- Odnosi trebaju biti spontani, srdačni i topli.

Naučnici ističu još veći značaj u saradnji porodice i škole kod djece s posebnim potrebama, bilo da su to djeca koja imaju teškoće u radu ili nadarena djeca.

U procesu odgoja darovitih učenika, mnogo je zadataka čija realizacija podrazumijeva zajedničko angažiranje roditelja i nastavnika, tako da je neophodno koordinirati njihove aktivnosti. Težište saradnje porodice i škole mora biti na osiguravanju što optimalnijih uvjeta za razvoj darovitih učenika. Neophodno je temeljnije pedagoško-psihološko osposobljavanje i nastavnika i roditelja darovitih učenika, kako bi mogli uspješno i pravovremeno podsticati razvoj njihovih interesiranja, talenata i kreativnosti.

Kod djece s poteškoćama u razvoju, saradnja porodice i škole je uspješnija ako je partnerski odnos uspostavljen znatno ranije (u saradnji roditelja sa zdravstvenom službom i predškolskom ustanovom).

Prilikom razmatranja potreba i načina za uspostavljanjem partnerskoga odnosa između roditelja djece s poteškoćama u razvoju i škole, treba imati na umu nekoliko nespornih činjenica: roditelji svakog djeteta kojima je stalo do njega su pristrasni; kada roditelji nemaju podršku u radu s djetetom, ubrzo nastaje umor i zasićenje; ta 
zasićenost se javlja i kod nastavnika ako škola i roditelji ne pokažu interes za njegov rad s djetetom.

U saradnji porodice i škole najveću ulogu u ostvarivanju iste ima nastavnik-razrednik, ali ne treba zaboraviti značajnu ulogu direktora i školskog pedagoga-psihologa u ostvarivanju saradnje.

O uspostavljenoj saradnji direktora sa svakim razrednikom, ovisit će realizacija odgojnoga plana škole u cjelini, a posebno ostvarivanje zadataka saradnje s roditeljima.

Školski pedagog je saradnik razredniku u neposrednome ostvarivanju odgojnih zadataka, pa i na planu saradnje s roditeljima. Od njegove stručne pomoći ovisi kvaliteta realizacije odgojnih zadataka razrednika.

\section{Dopisna saradnja porodice i škole}

Dopisna saradnja porodice i škole podrazumijeva komuniciranje preko pismene poruke između škole i roditelja.

Postoji poseban dokument, đačka knjižica, koja je namijenjena toj svrsi. Nekada nastavnici upražnjavaju i slanje pismenih poruka roditeljima o učenikovom radu i vladanju, i za tu svrhu koriste učenikovu svesku ili posebna pisma.

Ovaj oblik komuniciranja, također, je negativno obojen. Primjenjuje se samo kada nešto nije u redu, kada je učenik učinio nešto što se protivi kućnome redu, ili propisima školskog života.

Pismeni oblik komunikacije trebalo bi njegovati i kada razrednik treba da saopćiti pozitivne vijesti o učeniku: da napreduje u učenju, da se $u$ nečemu posebno ističe, da se pohvaljuje za određenu akciju, za pokazano ponašanje i slično, a to je veoma rijetko.

Mogu se uvesti sedmična ili mjesečna pisma. Ta pisma sadrže informacije o mnogim aktivnostima u koja su djeca uključena. Predstavljaju dobro sredstvo izvještavanja roditelja o procesu učenja koji se događa kroz nastavu i vannastavne aktivnosti, te mogu pozvati ili potaknuti roditelje da se i sami uključe u neke od tih aktivnosti. 
Cilj saradnje je pružanje uzajamne pomoći, razmjena iskustava i poboljšanje rada škole u svim vidovima djelatnosti. Zadaci dopisne saradnje porodice i škole su:

- Osposobljavanje za komunikaciju, interakciju i kooperaciju sa drugima;

- Razvijanje sposobnosti reprodukcije podataka primjenom naučnih činjenica, analize i sinteze;

- Osposobljavanje učenika za pravilno i pravovremeno dostavljanje informacija;

- Osposobljavanje učenika da razumiju značaj dopisne saradnje.

Pisanim oblicima komunikacije porodice i škole pripadaju sve vrste pisama, priopćenja, izvještaja, faks-poruka, SMS-ovi, e-mail-ovi, đačke knjižice, folderi itd.

Nedostatak dopisne saradnje porodice i škole, jeste što povratna informacija nije trenutačna, te postoji opasnost od nesporazuma.

\section{Uloga razrednika u saradnji porodice i škole}

Škola i roditelji u prvom redu sarađuju preko razrednika. On je posrednik i veza između roditeljskoga doma i škole. Od njegove umješnosti, stava, takta, spremnosti angažiranja u organizaciji ove saradnje, u najvećoj će mjeri zavisiti obim i kvalitet zajedništva škole i roditeljskoga doma.

Škola svojim godišnjim planom predviđa i oblike saradnje s roditeljskim domom, ali je organizacija uglavnom prepuštena razredniku.

Za uspješnu saradnju neophodno je da razrednik dobro upozna porodicu učenika, kako bi mogao pravilno da procjeni u čemu mu porodica može pomoći, a u čemu mu odmaže. Ukoliko to uspije da ostvari, razredniku će biti objašnjen najveći dio uzročnosti učenikovog ponašanja. Na osnovu toga, predlagaće odgojne mjere i uspostavljati različite oblike saradnje.

Često se dešava da razrednici pitanje saradnje preusko shvataju, pa ga stoga preusko i rješavaju. Često se dešava da je glavni cilj takve saradnje izvještavanje roditelja, naročito kada se učeniku sprema nešto 
loše u vezi učenja ili discipline, kako sama škola ne bi preuzela na sebe svu odgovornost. S druge strane, neki razrednici svode saradnju s roditeljima na traženje materijalne pomoći za razne školske potrebe. Sve to bitno umanjuje i omalovažava značaj i potrebu saradnje, čiji dublji smisao uvijek treba imati u vidu.

Uspješan rad razrednika sa roditeljima uvjetovan je planiranjem i programiranjem rada na početku školske godine. $\mathrm{Da}$ bi programiranje bilo uspješno, razrednik mora ispitati obrazovne potrebe i mogućnosti, mora poznavati strukturu, karakteristike za grupe roditelja, što podrazumijeva poznavanje odgojne klime $\mathrm{u}$ porodici, kao i sredine u kojoj se organizira odgoj i obrazovanje.

Pored međusobnog informiranja razrednika i roditelja, što je glavna aktivnost, u sadržaju programa saradnje mora postojati još i obrazovanje roditelja, te angažiranje roditelja. Rad na obrazovanju roditelja odnosi se na pedagoško obrazovanje roditelja.

Zadatak je razrednika da uputi roditelje na osnovne oblike, literaturu i načine obrazovanja, kako bi stekli adekvatna znanja iz oblasti pedagogije, psihologije, medicine itd.

Angažiranje roditelja, kao treća značajna dimenzija saradnje porodice i škole, ostvaruje se aktivnim učešćem roditelja u realizaciji zajedničkih zadataka. Nastavnik nastoji okupiti što veći broj roditelja, angažirati roditelje, zavisno od profila zanimanja, kako bi roditelji bili spona $\mathrm{u}$ saradnji $\mathrm{s}$ društvenom sredinom. Inicijativa razrednika $\mathrm{i}$ roditelja je potrebna, kako bi se formirali odjeljenski savjeti roditelja (oblik udruživanja roditelja radi zajedničkoga djelovanja) s namjerom da budu jedna od udarnih društvenih snaga na teritoriji škole.

Razrednik mora ispunjavati sve propisane funkcije na planu saradnje s porodicom. Omalovažavanje bilo koje dimenzije, ili njeno preuveličavanje, dovelo bi do jednostranosti, a time i do umanjenih rezultata na ovome planu.

Međutim, za uspješno ostvarivanje nabrojanih funkcija $u$ povezivanju porodice i škole, neophodni su lični kvaliteti razrednika, njegov pozitivan i pravilan stav prema roditeljima, učenicima i svome pozivu. Tek tada će on moći da za svoje ideje pridobije druge, da ih veže za odgojno-obrazovni rad u školi, te da ih pridobije za saradnju, 
koja će biti plod uvjerenja roditelja da se s razrednikom mora stvarati čvrsta veza.

Roditelji najčešće sarađuju sa onim razrednicima koji imaju smisla za komunikaciju, o kojima učenici imaju lijepo mišljenje, koji plijene svojom neposrednošću, koji pokazuju i dokazuju svoju dobronamjernost i za koje se zna da neće zloupotrijebiti ukazano im povjerenje. Takvi razrednici imaju šanse da budu inicijatori saradnje s roditeljima i da njihova inicijativa bude prihvaćena bez većeg otpora.

Razrednik mora odgovorno obavljati sve svoje dužnosti i funkcije, uz korektan odnos prema drugima i interesiranje za probleme drugih, a naročito uz stalno pokazivanje spremnosti pružanja pomoći, bez očekivanja da za to bude nagrađen ili pohvaljen. Ipak, mora biti oprezan kada traži od roditelja i učenika da se odreknu nekih svojih navika, stavova i uvjerenja, te kada želi da ih oduševi novim moralnim normama i društvenim vrijednostima. Također, mora pokazati dovoljno takta i mudrosti u mijenjanju pedagoške prakse roditelja, koja je često puna univerzalnih recepata, dogmatizma, prakticizma, formalizma i predrasuda.

\section{Metodologija istraživanja}

Cilj istraživanja je istražiti, analizirati, utvrditi i interpretirati zastupljenost i kvalitet dopisne saradnje porodice i škole u našim osnovnim školama; uporediti dopisnu saradnju u našim školama $\mathrm{s}$ primjerima dopisne saradnje iz Njemačke i Italije, kako bi se ta saradnja mogla unaprijediti.

Zadaci istraživanja:

- Istražiti koliko je za nastavnike općenito važna saradnja porodice i škole za uspjeh djeteta;

- Istražiti koliko su nastavnici zainteresirani za saradnju u cilju što uspješnijeg odgojno- obrazovnog procesa;

- Istražiti kojom vrstom saradnje porodice i škole nastavnici dobivaju bolje rezultate;

- Istražiti koliko je frekventna dopisna saradnja porodice i škole;

- Istražiti na koji način nastavnici korespondiraju s roditeljima; 
- Istražiti koliko često roditelji odgovore nastavnicima na pismene poruke;

- Istražiti uzroke zbog kojih nastavnici najčešće korespondiraju s roditeljima;

- Istražiti kako se, po mišljenju nastavnika, može poboljšati efikasnost dopisne saradnje u našim školama;

- Istražiti sličnosti i razlike dopisne saradnje porodice i škole u našim školama i školama u Italiji i Njemačkoj na osnovu dokumentacije?

U istraživanju je kao osnovna metoda korištena empirijskoneeksperimentalna, servej metoda i rad na dokumentaciji. U okviru metode rada na dokumentaciji raspon dokumenata je vrlo širok, ali je za ovo istraživanje korištena dokumentacija dopisne saradnje porodice i škole iz tri evropske države.

Glavni instrument je upitnik koji je posebno konstruiran za ovo istraživanje. Upitnik je sastavljen od osam pitanja kombiniranog tipa.

Istraživanje je vršeno u dvije osnovne škole u Zavidovićima. Populaciju za istraživanje sačinjavali su nastavnici razredne i predmetne nastave. Ukupno je bilo 40 ispitanika.

\section{Rezultati istraživanja}

Rezultati dobiveni ispitivanjem nastavnika

Postavljenim pitanjem nastavnicima: Koliko je po vama važna saradnja porodice $i$ škole za uspjeh djeteta?, nastojali smo istražiti važnost saradnje porodice i škole za odgojno-obrazovni proces. Slijedi grafički prikaz rezultata: 


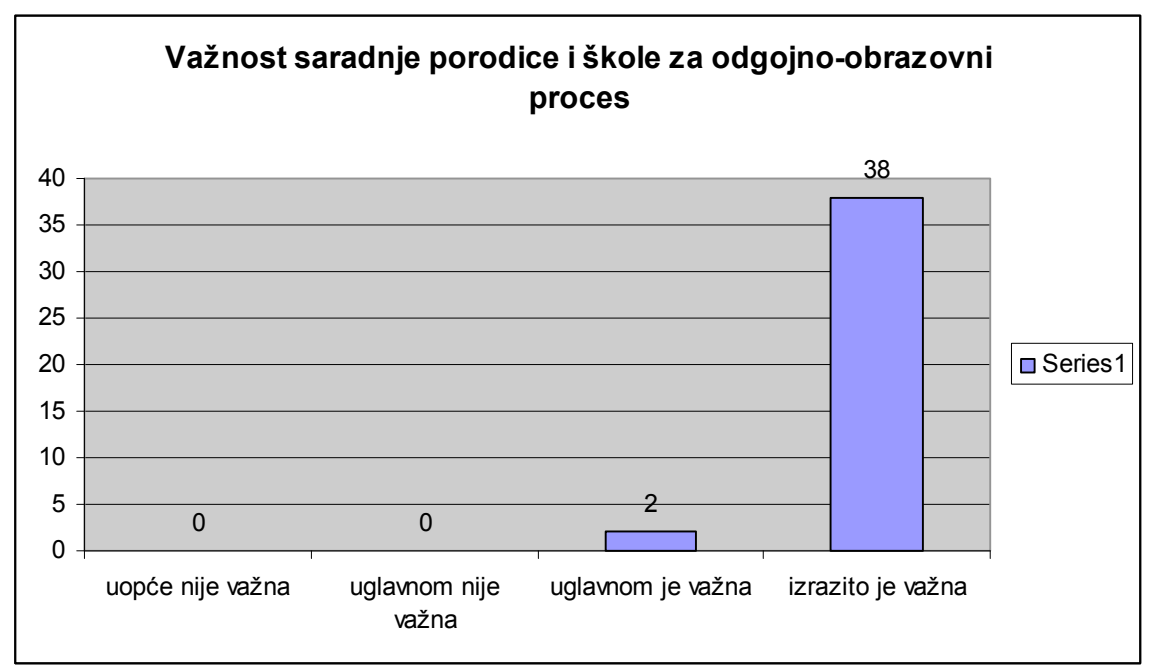

Grafikon 1. Grafički prikaz stavova nastavnika o važnosti saradnje porodice i škole u odgojno-obrazovnom procesu

Rezultati predstavljeni Grafikonom 1., pokazuju kako većina nastavnika iz dvije osnovne škole u Zavidovićima smatra, da je saradnja porodice i škole izrazito važna za uspjeh djeteta, čime je i potvrđena prva hipoteza. Nakon toga, značajni su rezultati koji govore o nivou zainteresiranosti nastavnika za saradnju s roditeljima u cilju što uspješnijeg odgojno-obrazovnog procesa. Slijedi grafički prikaz i analiza.

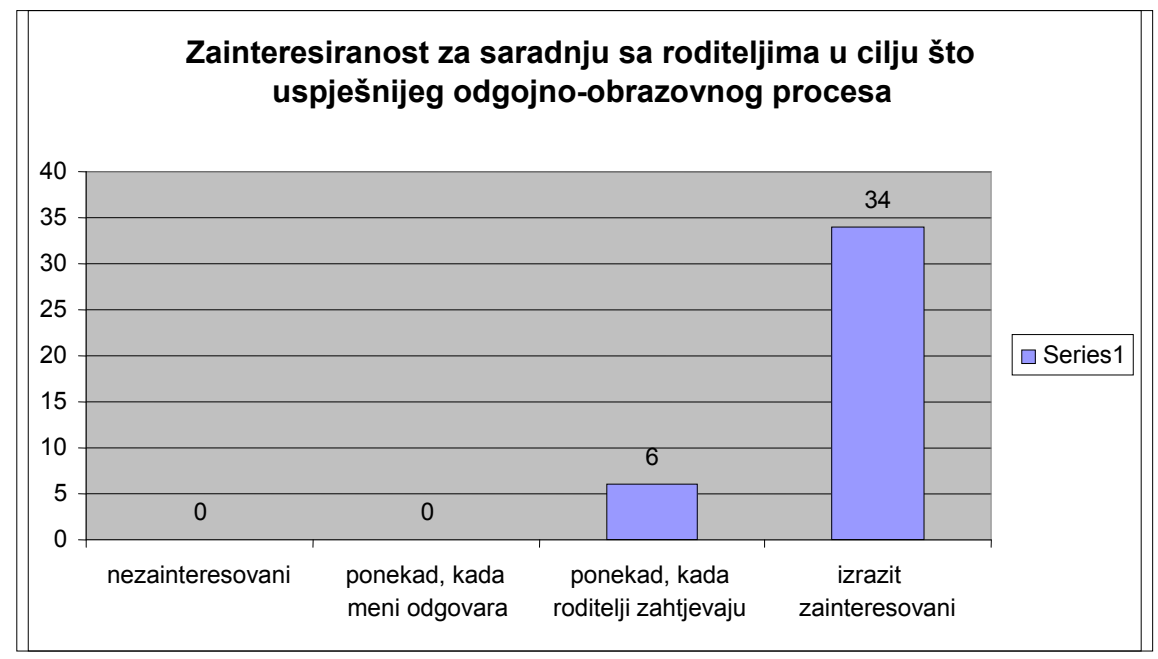

Grafikon 2. Grafički prikaz zainteresiranosti nastavnika za saradnju s roditeljima 
Rezultati su vidni iz odgovora na drugo pitanje iz upitnika za nastavnike: Da li ste zainteresirani za sardanju s roditeljima u cilju što uspješnijeg odgojno-obrazovnog procesa?

Iako je vidno iz Grafikona 1., da je nastavnicima saradnja s roditeljima izrazito važna, iz Grafikona 2., se vidi da ih je već manje izrazito zainteresirano za saradnju, te da ih je 8 od 40 zainteresirano samo ako to roditelji traže.

Istražili smo i stavove nastavnika o tome kojom vrstom saradnje porodice i škole nastavnici dobivaju bolje rezultate. Slijedi grafički prikaz i analiza:

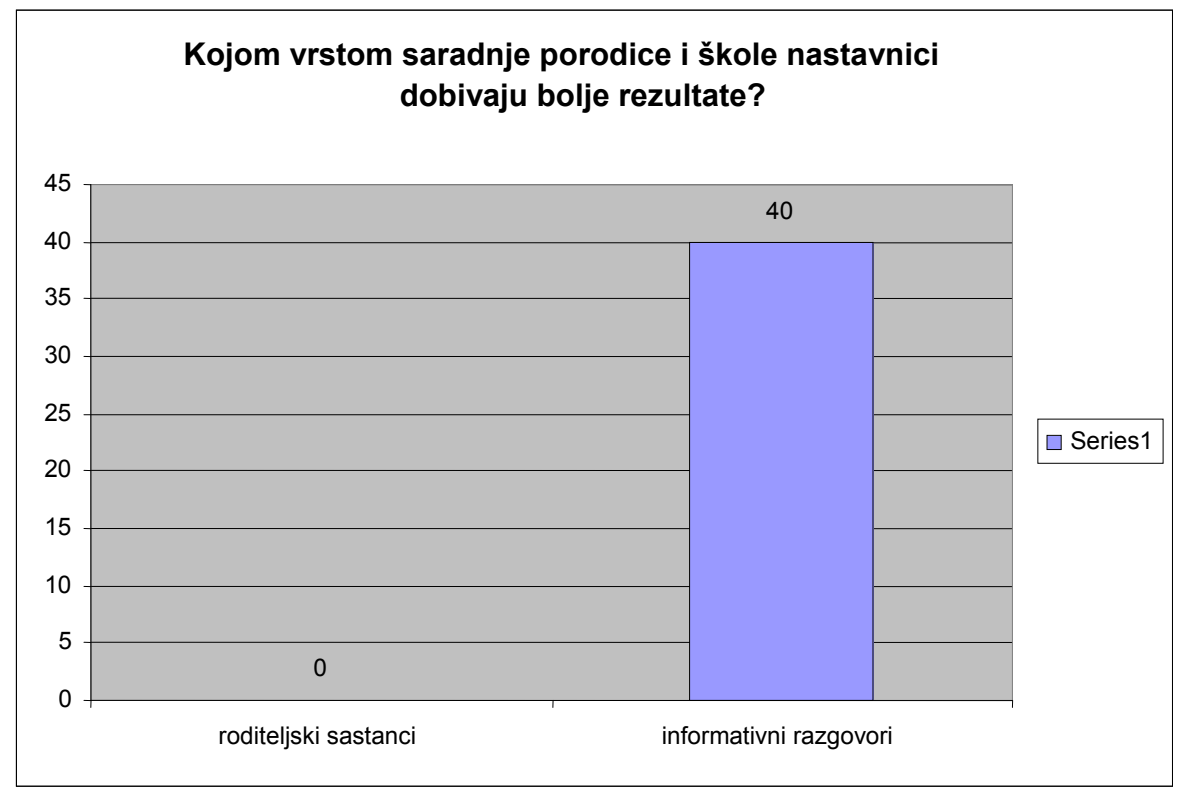

Grafikon 3. Grafički prikaz stavova nastavnika o tome koja vrsta saradnje daje bolje rezultate

Grafikon 3., pokazuje stopostotni procenat odgovora da su to informativni sastanci, čime je i potvrđena treće hipoteza, kako su efikasniji rezultati u individualnim susretima nastavnika i roditelja.

Ključno pitanje interesa ovoga istraživačkoga nastojanja je bilo, koliko često nastavnici koriste dopisnu saradnju kao vid saradnje porodice i škole? Slijedi grafički prikaz i analiza: 


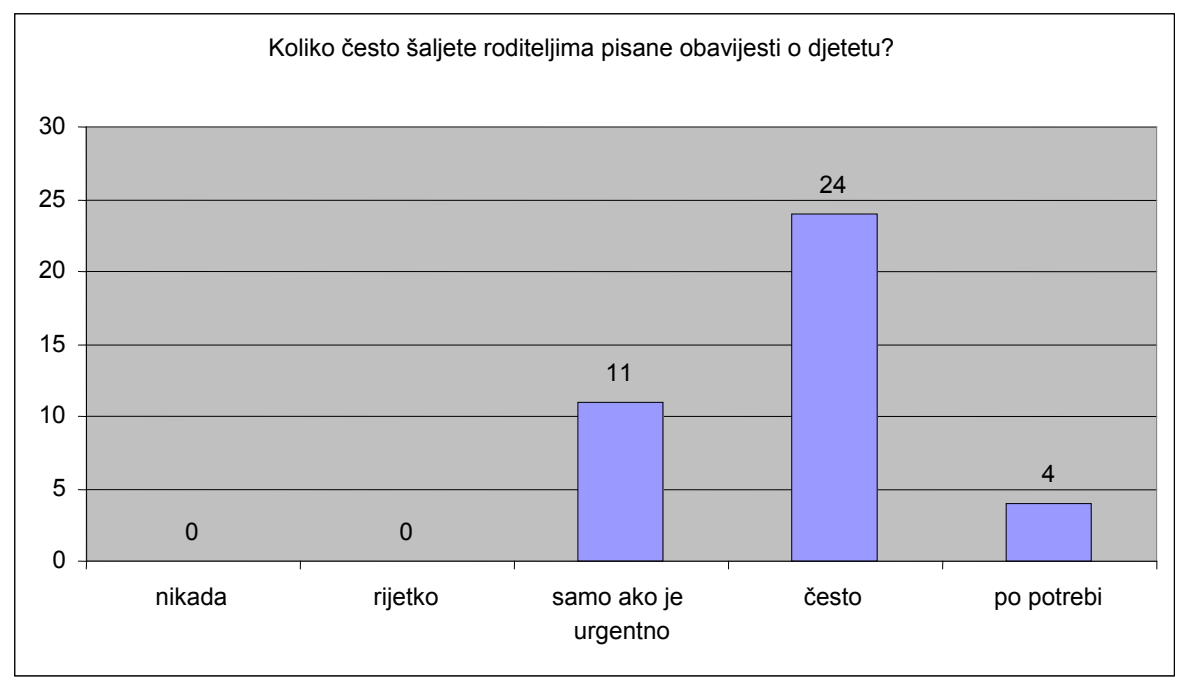

Grafikon 4. Grafički prikaz stavova nastavnika o učestalosti dopisne saradnje s roditeljima

Od anketiranih nastavnika, njih više od pola korespondira $\mathrm{s}$ roditeljima često, a njih deset to radi samo ako je urgentno. Time je potvrđeno kako u našim školama dopisna saradnja porodice i škole nije dovoljno razvijena ni kvantitativno ni kvalitativno.

Dalje nas je interesiralo na koji način nastavnici korespondiraju s roditeljima? Slijedi grafički prikaz i analiza:

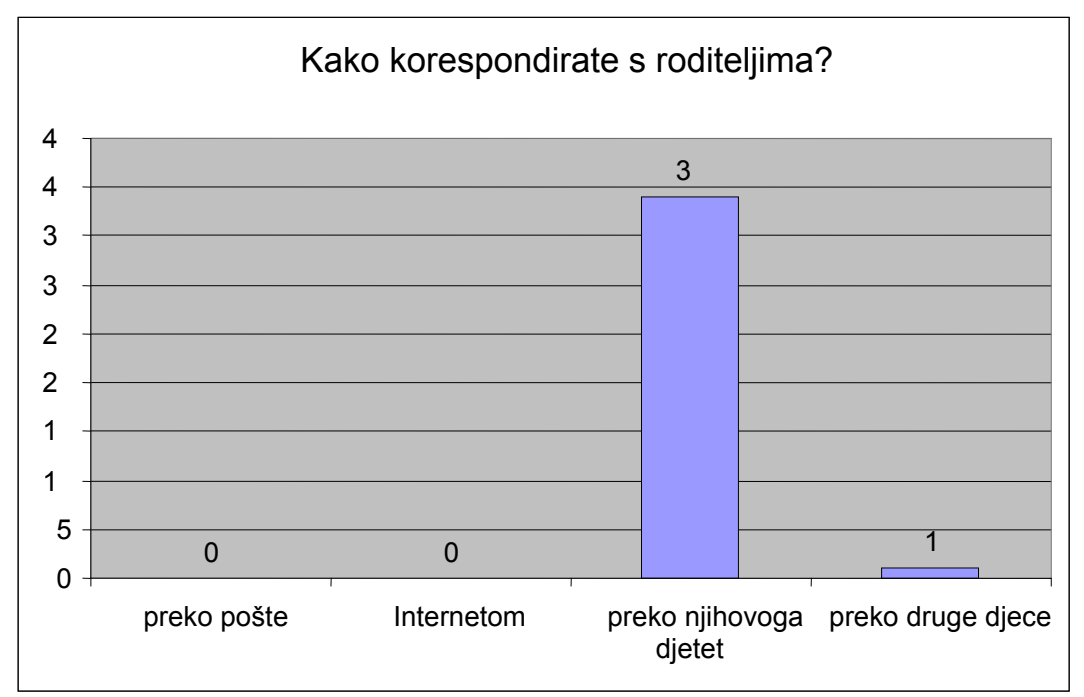

Grafikon 5. Grafički prikaz stavova nastavnika o načinu dopisne saradnje s roditeljima 
$\mathrm{Na}$ grafikonu se jasno vidi kako nastavnici uglavnom korespondiraju s roditeljima preko njihove djece, odakle slijedi da je dopisna saradnja porodice $\mathrm{i}$ škole jako zahtjevna, traži dosta znanja i materijalnih sredstava i porodice $\mathrm{i}$ škole, čega u našim porodicama $\mathrm{i}$ školama nedostaje.

Značajni su i rezultati koji govore o tome koliko često roditelji odgovore nastavnicima na pismene poruke? Slijedi grafički prikaz i analiza:

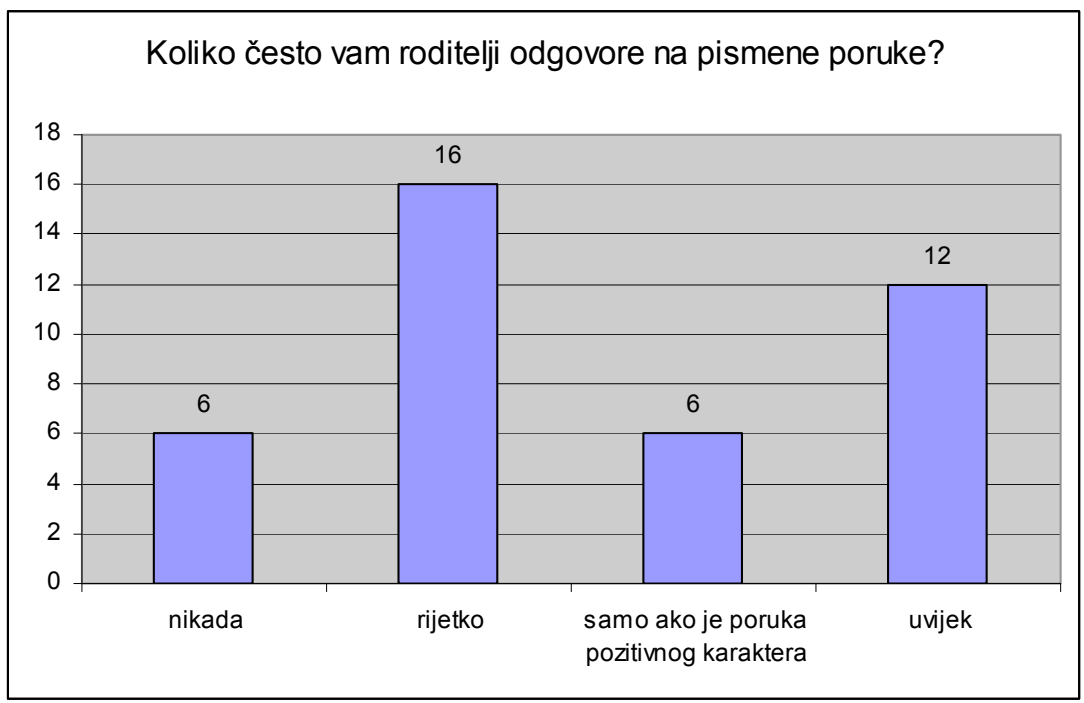

Grafikon 6. Grafički prikaz stavova nastavnika o načinu dopisne saradnje s roditeljima

Iz Grafikona 6., se može uočiti kako su odgovori nastavnika različiti iz čega slijedi da zainteresiranost roditelja za dopisnu saradnju porodice i škole zavisi od roditelja do roditelja. Ipak, najveći broj odgovora je da to roditelji rade rijetko.

Interesirali su nas razlozi zbog kojih nastavnici korespondiraju s roditeljima. Slijedi grafički prikaz i analiza: 


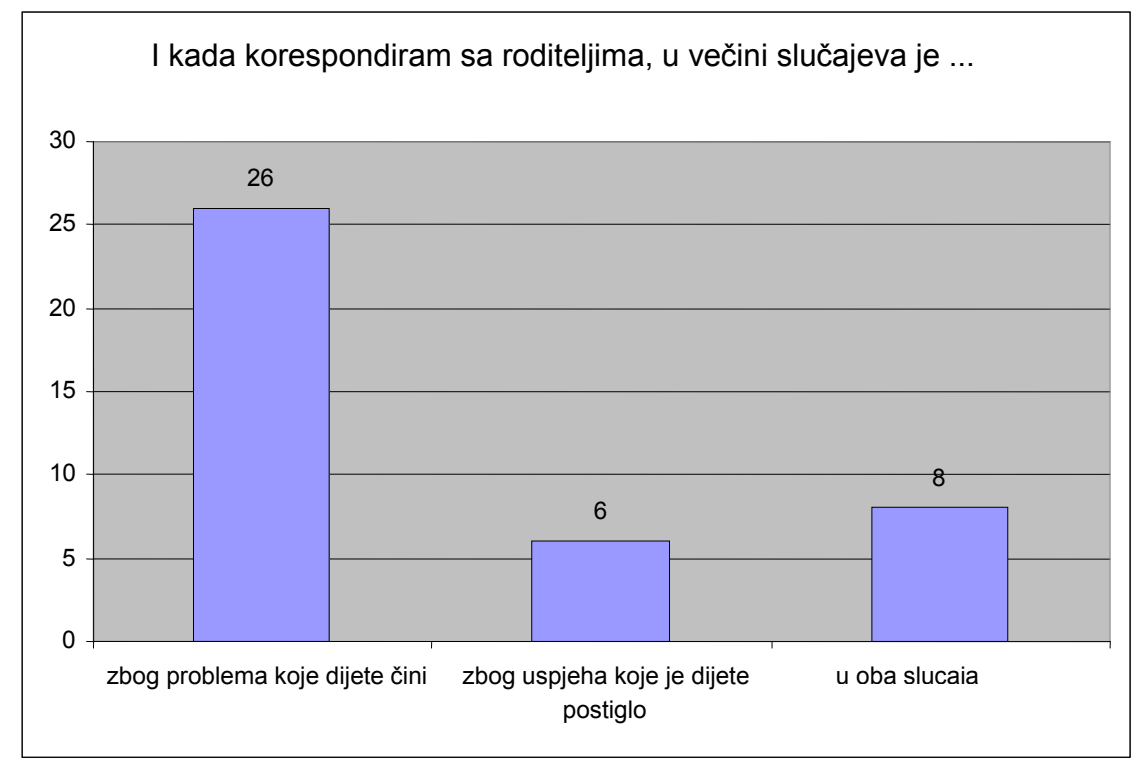

Grafikon 7. Grafički prikaz stavova nastavnika o razlozima korespondencije s roditeljima

Grafikon broj 7., pokazuje kako nastavnici uglavnom korespondiraju s roditeljima zbog problema koje djeca čine, što je negativno obojeno, jer bi se možda bolji rezultati u odgojnoobrazovnome procesu djeteta postizali kada bi većina nastavnika više pismeno izvještavala roditelje o uspjesima koja djeca postižu. Sa ovim je potvrđeno da su, ipak, nastavnici više zainteresirani da obavijeste roditelje o problemima koje dijete čini, nego o njegovim uspjesima.

Interesirao nas je stav nastavnika o tome kako se može poboljšati efikasnost dopisne saradnje u našim školama? Slijede rezultati: 


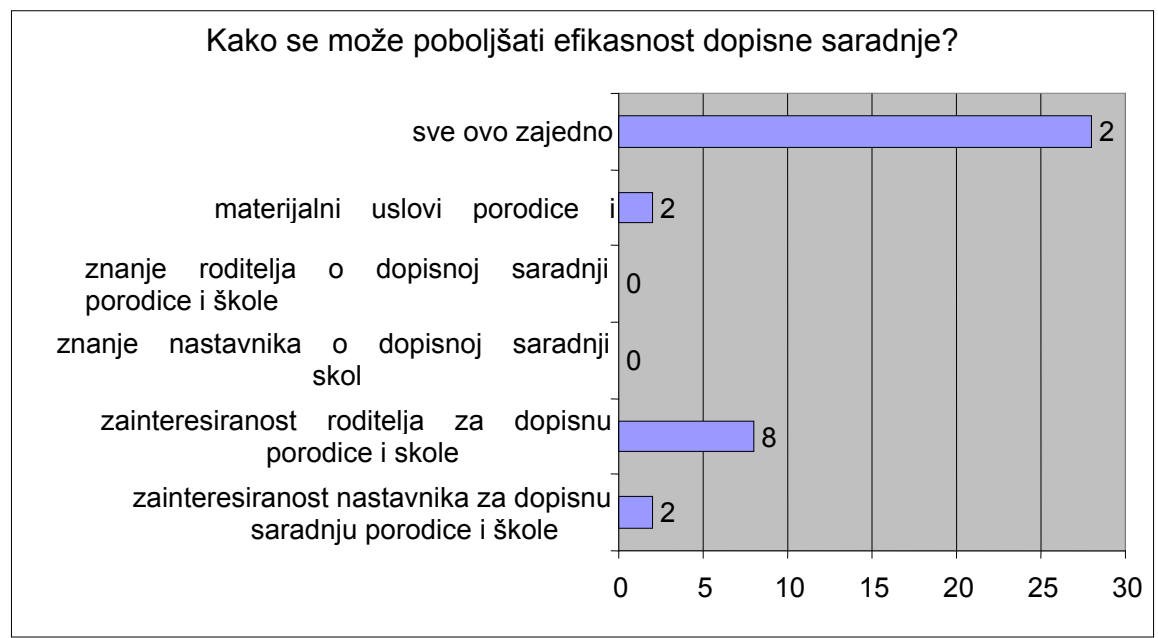

Grafikon 8. Grafički prikaz prijedloga nastavnika o razlozima korespondencijes roditeljima

Od 40 ispitanih nastavnika, njih 28 smatra kako se i u našim školama može poboljšati efikasnost dopisne saradnje porodice i škole, kad bi se u školi i u porodici poboljšali materijalni uvjeti, zainteresiranost nastavnika i roditelja za dopisnu saradnju, te njihovo znanje o dopisnoj saradnji porodice $\mathrm{i}$ škole.

Njih 8 smatra kako bi se efikasnost dopisne saradnje porodice i škole mogla poboljšati ako bi se povećala zainteresiranost roditelja za istu. Dva nastavnika smatraju da će se isto desiti ako se poveća zainteresiranost samih nastavnika, a dva nastavnika smatraju da će se efikasnost poboljšati ako se samo poprave materijalni uvjeti škole i porodice.

\section{Rezultati dobiveni istraživanjem dokumentacije}

Đačka knjižica

Na slikama 2., 3. i 4., prikazane su stranice đačke knjižice iz Italije: 
Ministero dell'Istruzione, dell' Liniversità e tella Ricerca

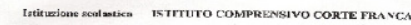

1

corte r ranca

(AS)

Pines C. Conareo, s

DOCUMENTO DI VALUTAZIONF
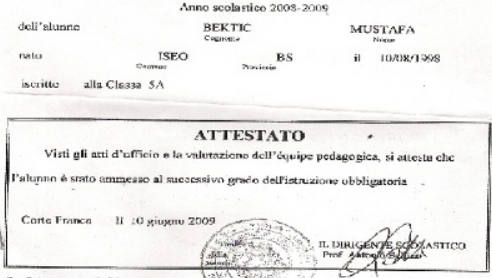

Co

Slika 2.

$\mathrm{Na}$ Slici 2., nalaze se osnovni podaci o učeniku koji pohađa $\mathrm{V}$ razred osnovne škole.

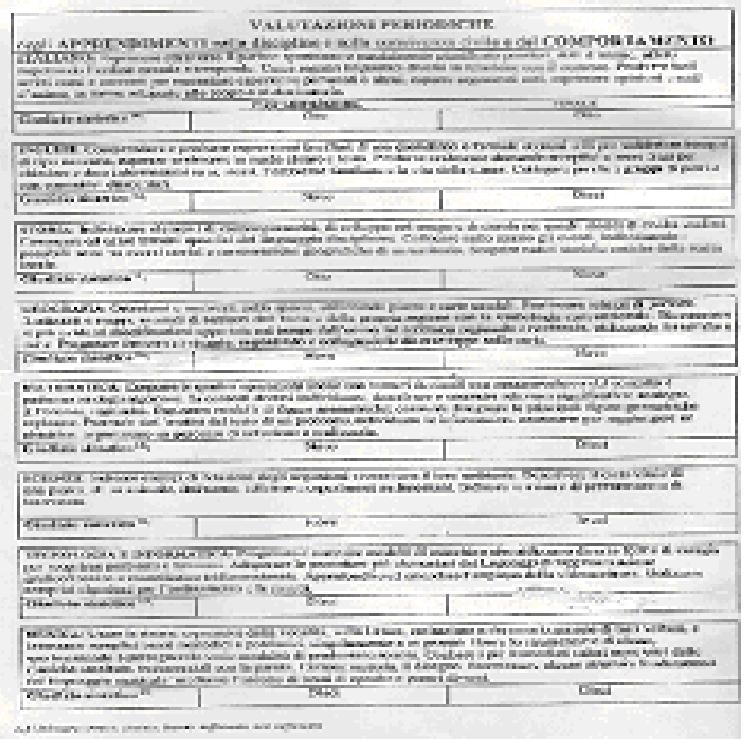

Slika 3.

Slika 3. prikazuje opisne i brojem rangirane ocjene navedenog učenika po predmetima. 


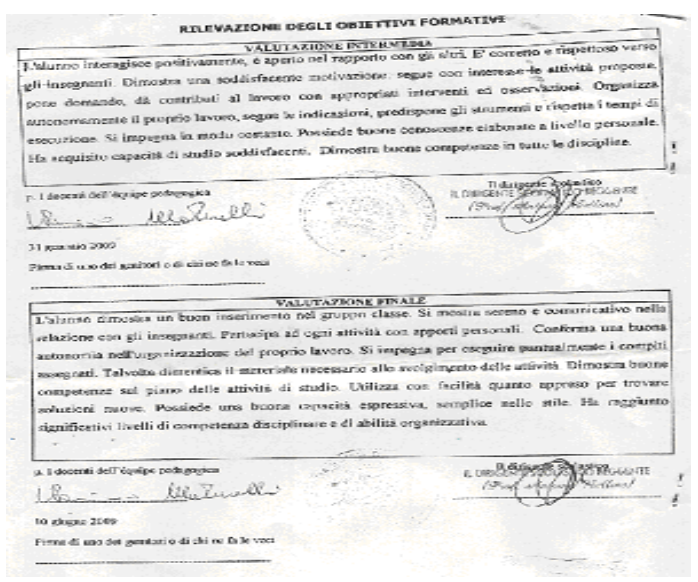

Slika 4.

Na posljednjoj je strani đačke knjižice (Slika 4.) samo opisna ocjena za prvu kvalifikaciju i za kraj školske godine.

Na slikama 5. i 6., koje slijede, prikazane su stranice đačke knjižice iz Njemačke:

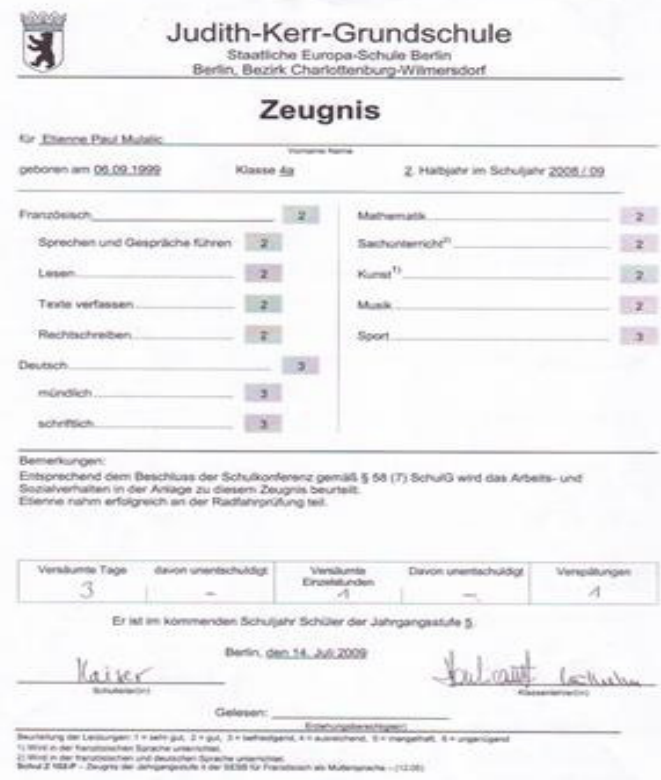

Slika 5. 


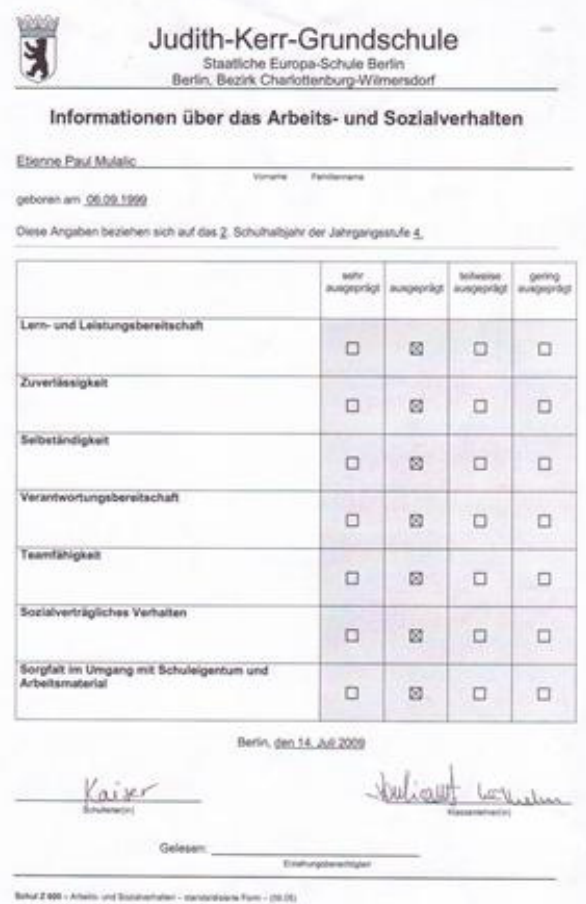

Slika 6.

Pri prvome susretu s ovom vrstom dokumenata osnovnih škola u Njemačkoj, može se primijetiti kako se sama forma dokumenta razlikuje od ranije prikazanog na slikama broj 2., 3. $i$ 4., dokumenta đačke knjižice iz Italije. Sadržaji ove đačke knjižice učenika V razreda su osnovni podaci na samome zaglavlju sa ostalim osnovnim podacima škole koju dijete pohađa. Na prikazanim marginama, u dnu dokumenta, su brojčane ocjene kojima je vrednovano učenikovo znanje. Na posebno odvojenoj vertikalnoj margini su praznine za broj izostanaka, sortirani prema opravdanju.

Ono što je interesantno kod ove vrste ocjenjivanja, jeste da ocjene koje rangiraju kvalitet znanja idu u suprotnom smjeru od našega brojčanog ocjenjivanja. Naime, njihov će odličan učenik za najbolji uspjeh dobiti ocjenu 1, a najgori 5.

$\mathrm{U}$ drugome dokumentu, prikazanom slikom broj 6 su tabele sa sposobnostima i navikama učenika (socijalizacija, radne navike) koje svaki razrednik rangira prema uspjehu učenika. Nastavnik stavlja znak 
$\mathrm{X}$ u kvadratić ispod odgovarajućeg stepena napretka učenika (Vrlo uspješan, uspješan, malo uspješan, neuspješan).

Na slikama 7., 8. i 9., koje slijede, prikazane su stranice đačke knjižice iz Bosne i Hercegovine.

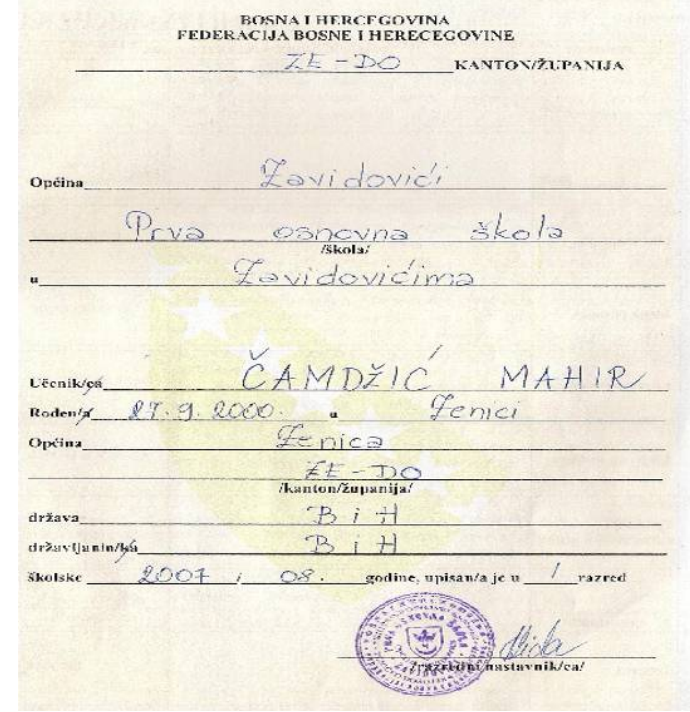

Slika 7.

Na Slici 7., se nalaze osnovni podaci o učeniku koji pohađa V razred osnovne škole.

Slika 8., prikazuje opisne i brojem rangirane ocjene navedenog učenika po predmetima. 


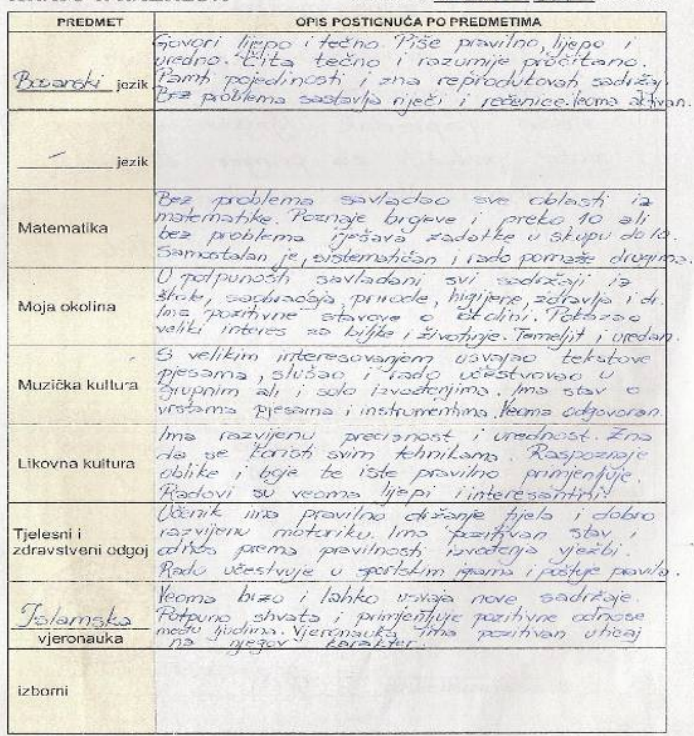

Slika 8.

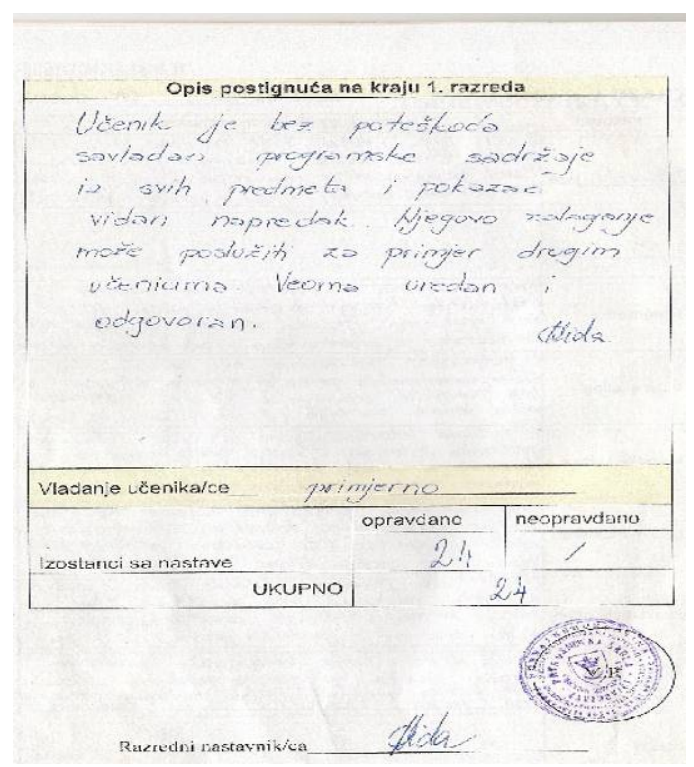

Slika 9.

Na posljednjoj strani đačke knjižice je samo opisna ocjena za prvu kvalifikaciju i za kraj školske godine. 
Kao prvi primjer dopisne saradnje porodice i škole, prikazane su đačke knjižice iz tri evropske zemlje. Jasno se može uočiti da je forma đačke knjižice u sve tri zemlje slična. Osim što sama forma dokumenta izgleda drugačije, svi ostali podaci koji se nalaze na njima su isti, svi vrednuju znanje brojčanom ocjenom i svi opisuju sposobnosti i napredak u društvenom smislu. U đačkim knjižicama Italije i Bosne i Hercegovine, na kraju prve klasifikacije i na kraju školske godine, pišu se zapažanja o učeničkim znanjima, ovladanim sposobnostima i općim karakternim osobinama.

U Bosni i Hercegovini se ovaj vid dopisne saradnje porodice i škole najviše praktikuje i zaveden je kao jedan od osnovnih dokumenata u školama.

\section{Sveska za dopisnu saradnju roditelja i nastavnika}

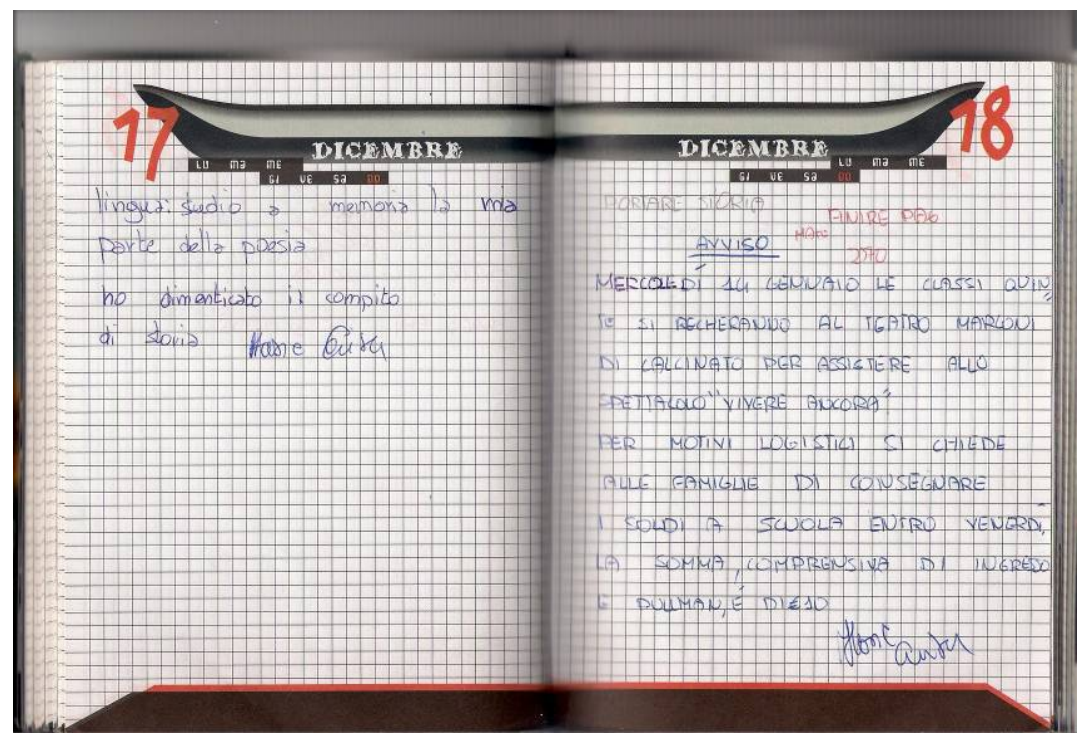

Slika 10.

Od dokumentacije je za saradnju škole i roditelja u Italiji (Slika 10.) i Njemačkoj (Slike 11. i 12.) izrazito bitna sveska za dopisnu saradnju porodice i škole. Ima je svako dijete i uvijek se nalazi u učeničkim torbama. Na početnoj stranici te sveske je prostor za lične podatke učenika, a u svesci su odštampani svi datumi u školskoj godini. Ako nastavnik ili roditelj ima poruku koju želi da proslijedi, to može učiniti preko iste. Poruka treba biti tačna, uredna i precizna. $\mathrm{Na}$ 
kraju svake poruke stoji potpis autora, kao i na odgovoru. Poruke se pišu na stranicama prema datumu, te ukoliko roditelj ili nastavnik nema ništa za poručiti, stranice s tim datumima ostaju nepopunjene.

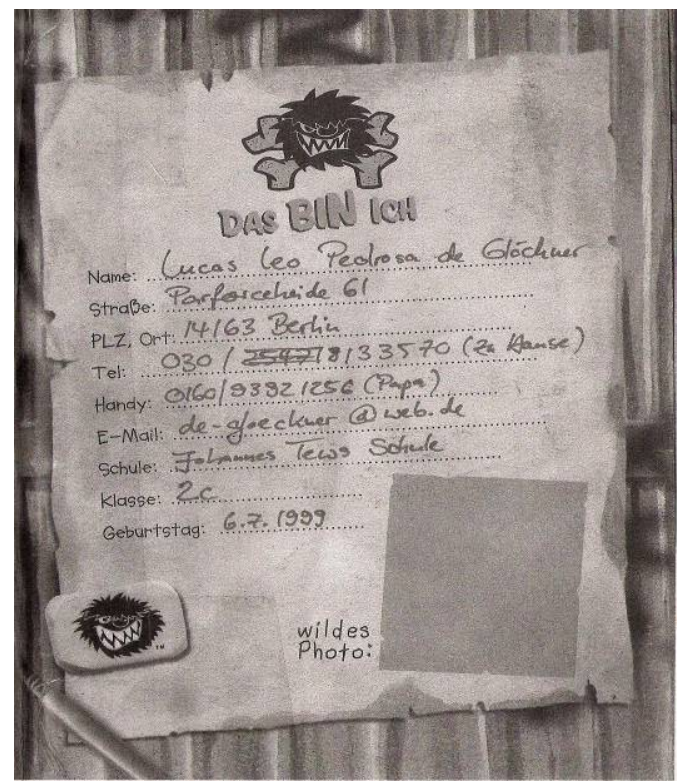

Slika 11.

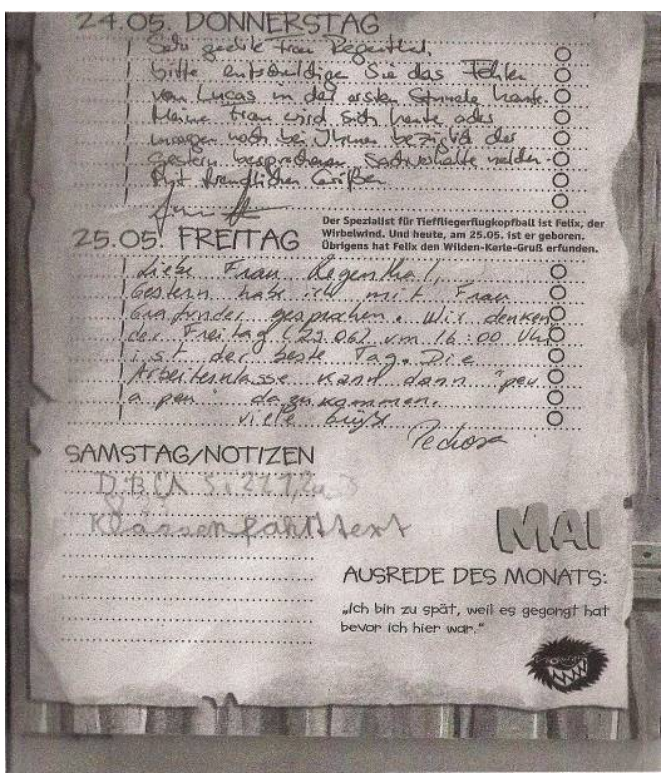

Slika 12. 
Upoređujući taj vid dopisne saradnje porodice i škole u ove tri evropske zemlje, konstatirali smo da takve sveske postoje u Njemačkoj i Italiji. No, u školama u Bosni i Hercegovini nismo naišli na takav vid dopisne saradnje porodice i škole.

\section{Informativni dokumenti kojima nastavnik izvještava roditelje o vannastavnim aktivnostima}

Na prikazanim slikama su dokumenti dopisne saradnje iz Italije (Slika 13.) i Njemačke (Slika 14.) korišteni da bi se roditelji obavijestili o predstojećim aktivnostima koje organizira škola, aktiv jednoga razreda ili sam nastavnik.

ISTITUTO COMPRENSIVO DI CORTE FRANCA

SCUOLA PRIMARIA

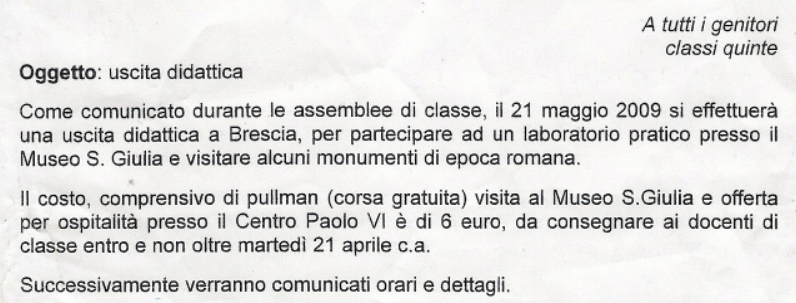

\section{Slika 13.}

Poruke upućene ovim putem su dosta precizne, jasne i ispunjene svim potrebnim informacijama. Na zaglavlju svakog dokumenta se nalazi potpuni naziv škole, datum i razred (Slike 13. $i$ 14.) Na nekim dokumentima po slobodnoj volji autora može stajati adresa škole, djelovodni broj i ostali zakonom zavedeni podaci (Slika 14.) 


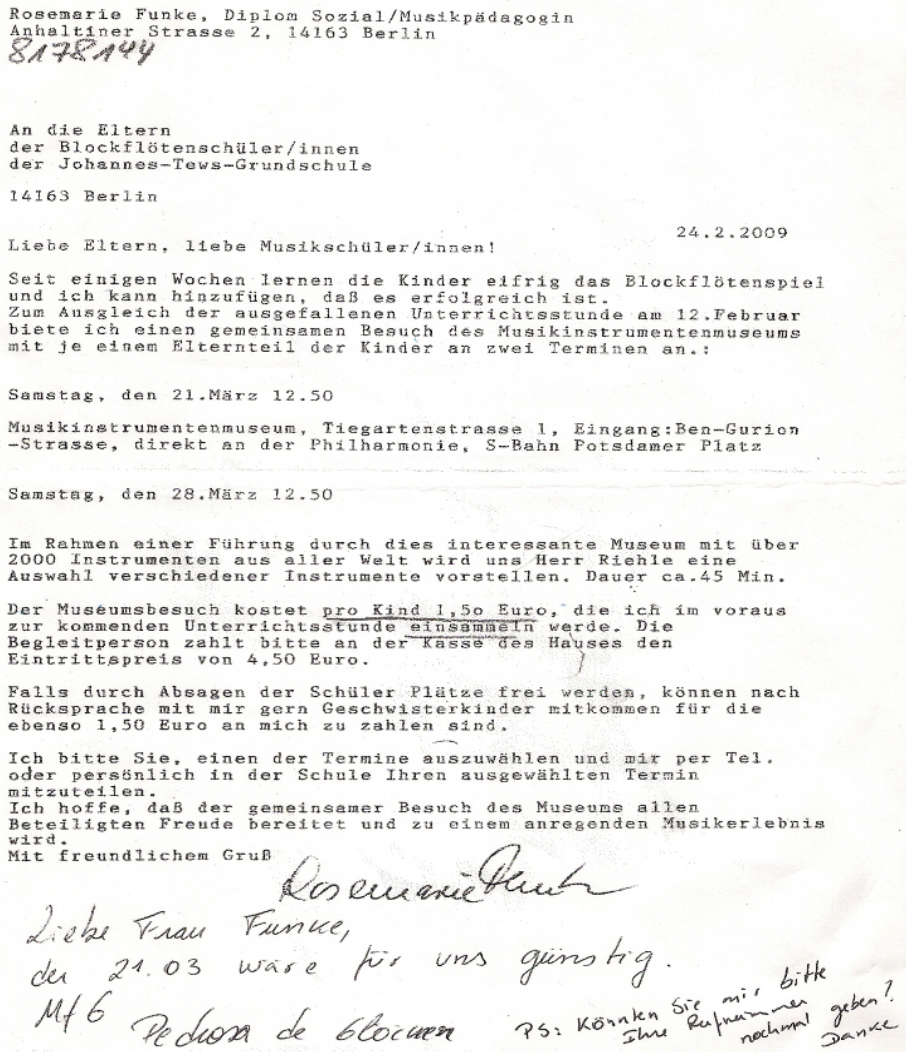

Slika 14.

Roditelji su upućeni u sve detalje organizacije priredbe ili posjete. Obaviješteni su o potrebi plaćanja aktivnosti, te se svakome roditelju na posljednjem roditeljskom sastanku prikaže raspodjela prikupljenih finansija u toku jedne kvalifikacije ili cijele školske godine.

Ovakav dokument se šalje roditeljima preko učenika u periodu od nekoliko dana prije same realizacije dokumentom navedene aktivnosti, te je i roditelju pružena mogućnost da napiše odgovor $u$ dovoljno dugom periodu prije početka aktivnosti. Roditelji svoj odgovor mogu pisati u Dopisnu svesku (Slike 10., 11., 12.) prema odgovarajućem danu i datumu, ili po želji odgovoriti direktno na dobiveni dokument čime bi isti morali vratiti u školu, kao što je to učinio roditelj na dokumentu. (Slika 14.) 
Komunikacija preko pisanog dokumenta (Slika 14.) bi pružila mogućnost nastavniku da informaciju prikupljanja novca za određene aktivnosti ili kupnju potrebnog materijala za rad, mnogo lakše prenosi roditelju, bez ustručavanja ili verbalnog konflikta ukoliko neki od roditelja ne podržava prenesenu ideju. Sama komunikacija pisanim slovima bi mogla da predstavlja bitnu sponu u lancu razvoja naše škole, te bi cjelokupna ideja, zajedno sa svojom realizacijom, olakšala razvoj i zaživljavanje novog školskog sistema.

\section{Zaključak}

Saradnju s porodicom, nastavnik ne smije shvatiti kao slučajnu, prigodan kampanjski proces. To mora biti promišljen, organiziran i planski posao, stalna briga nastavnika, koja ulazi u prvi plan njegovih odgojnih nastojanja. Učitelj treba biti uvjeren kako se odnos učenika prema učenju i radu, ne formira samo u školi nego i u porodici.

U međusobnome razumijevanju i iskrenoj dobro organiziranoj saradnji ovih dvaju najodlučnijih faktora u odgoju djece, leži velika snaga i uvjet za postizanje dobrih rezultata u odgoju mladoga naraštaja.

Naša zemlja je $u$ tranziciji i svakodnevni smo suočeni sa stalnim promjenama u društvu i društvenim institucijama. Promjene se dešavaju i u školstvu, jer je danas školovanje djece slobodnije, razigranije, a i roditelji nisu više pasivni posmatrači. Oni su danas subjekti kojima je zakonski omogućeno, da budu ravnopravni sudionici u odvijanju odgojno-obrazovnoga procesa.

Danas se sve više nameće potreba angažmana škole, ali i društva u cjelini, kao dopuna i potpora poljuljanome porodičnom odgoj. Dijete je veoma osjetljivo, ali i podvrgnuto velikim intelektualnim naporima, pa se nameće potreba kvalitetnije i kvantitativnije saradnje porodice i škole. Tako je u uvjetima prisne saradnje roditelja i škole moguće stalno pratiti rad i razvoj učenika i prućiti mu neophodnu pomoć. Saradnja porodice sa školom treba se planirati svake godine. Roditelji danas razumiju važnost pomoći koju trebaju pružiti svojoj djeci, a odgojno-obrazovne institucije su im dužne pomoći u educiranju.

Istraživanje je pokazalo kako nastavnici smatraju da je saradnja porodice i škole veoma bitna za uspjeh djece u odgojno-obrazovnome 
procesu. Većina ispitanih nastavnika je izrazito zainteresirana za saradnju s roditeljima u cilju što uspješnijega odgojno-obrazovnog procesa. Oni su se u stopostotnom procentu izrazili da bolje i potpunije rezultate $\mathrm{u}$ radu $\mathrm{s}$ roditeljima dobivaju preko informativnih sastanaka. Kada je riječ o dopisnoj saradnji porodice i škole, nastavnici su se izjasnili (24 od 40 nastavnika) da oni taj vid saradnje porodice i škole koriste samo ako je urgentno. Njih deset se izjasnilo da to radi često, a korespondiraju s roditeljima uglavnom preko njihove djece. Sve ovo ukazuje na nizak stepen upotrebe dopisne saradnje porodice i škole, što zbog nedovoljne zainteresiranosti i neznanja, što zbog nedostatka materijalnih sredstava škole i porodice.

Dopisna saradnja porodice i škole zahtijeva znanje i vrijeme od strane nastavnika, ali i od strane roditelja. Korespondencija je uglavnom zbog problema koje dijete čini, što je veoma negativno obojeno, jer bi u većini slučajeva bolje rezultate dala dopisna saradnja porodice sa školom kada bi bila iz razloga uspjeha pojedinog djeteta. Kada se povuče paralela između dopisne saradnje u školama Bosne i Hercegovine i školama Italije i Njemačke, s pravom se na osnovu dostupne dokumentacije i dobivenih rezultata ovoga istraživanja može zaključiti, kako je dopisna saradnja porodice i škole razvijenija i svakodnevno zastupljenija mnogo više u navedenim zemljama nego u Bosni i Hercegovini. U školama Italije i Njemačke učenici imaju posebne sveske za svakodnevnu dopisnu saradnju nastavnika i roditelja, pa je tako komunikacija brža, preciznija i sadržajnija.

$\mathrm{Na}$ kraju konstatiramo kako bi dopisna saradnja u školama Bosne i Hercegovine mogla i trebala poboljšati i kvalitativno i kvantitativno u cilju lakšega i efikasnijega odgojno-obrazovnog procesa. Da bi se to postiglo potreban je angažman i škole i roditelja, pa $\mathrm{i}$ drugih institucija. Time se pokreće pitanje o materijalnim $\mathrm{i}$ finansijskim mogućnostima naše zemlje da unaprijedi i modernizira školski sistem u cjelini.

Nastavnici i roditelji zajedno u posebno oformljenim timovima na lični zahtjev, mogu konstituirati model međusobne komunikacije na primjeru za nas modernih škola Evrope pa i dalje.

Po uzoru svesaka za dopisnu saradnju, navedenih u ovome radu, te poslije i drugim idejno razvijenim načinima, mogla bi se započeti prava mala evolucija i razvoj ovoga vida saradnje u cilju suzbijanja 
nekontroliranosti u ponašanju djece danas, izazvane naglim elektronskim razvojem, pa i pretjeranom zaposlenošću roditelja (mnogi roditelji opravdavaju nedolazak na informativne sastanke jer, (...) previše su zaposleni). Smatramo kako je već dobar dio populacije stanovništva u našoj zemlji u mogućnosti uspostaviti vezu elektronskom poštom iz vlastitog doma da bi izbjegli neredovne dolaske na informativne sastanke, s nastavnicima ili neredovno pravdanje izostanaka djeteta s nastave.

\section{Literatura:}

1. Ajanović, Dž. - Stevanović, M., Školska pedagogija, Prosvjetni list, Sarajevo, 1998.

2. Ćatić, R. - Stevanović, M., Pedagogija, Pedagoški fakultet, Zenica, 2003.

3. Ćatić, R., Slika o sebi djece potpunih i nepotpunih porodica, Planjax, Tešanj, 1997.

4. Ćatić, R., Osnovi porodične pedagogije, Pedagoški fakultet, Zenica, 2005.

5. Grandić, R. - Karić, M., Pedagogija, Tuzla Book, Tuzla, 2009.

6. Hitrec, G., Kako pripremiti dijete za školu, Školska knjiga, Zagreb, 1991.

7. Mandić, P., Saradnja porodice i škole, Svjetlost, Sarajevo, 1980.

8. Mulić, V., Škola i porodica - putevi i stranputice, Didaktički putokazi, br. 24/2001., str. 18 -22., Pedagoški zavod i Pedagoški fakultet, Zenica, 2001.

9. Nastavni plan i program za osnovnu škole ZE-DO kantona, Ministarstvo za obrazovanje, kulturu i sport ZE-DO kantona, Zenica, 1999.

10. Pašalić-Kreso, A., Koordinate obiteljskog odgoja, Jež, Sarajevo, 2004.

11. Stevanović, M., Odgoj u obitelji i školi, Mara, Pula, 1997. 
Prof. dr. Refik Ćatić, P.H.D., \& Samira Karajbić, B.A.

\section{CORRESPONDING COOPERATION OF FAMILY AND SCHOOL}

\section{SUMMARY}

Theme of this paper is related to features and the role of family and school as two key factors in educational work.

Research goal was to research and interpret representation and quality of corresponding cooperation in our primary schools; to compare corresponding cooperation in our schools with examples of corresponding cooperation from Germany and Italy and to suggest means for improving this cooperation.

Basic methods which were used in this research are: empiric non-experimental method, survey method and work on the documentation. Main instrument in this research was a teacher questionnaire. Research was conducted in two primary schools in Zavidovici. Sample was 40 teachers.

An obvious conclusion can be drawn that many possibilities which corresponding cooperation may present are not fully exploited in our country, compared to international experience.

Key words: corresponding cooperation, parents, school, head teacher, school documentation 
الأستاذ الدكتور رفيق تشاتيتش والأستاذة سميرة كارايبيتش

\section{التعاون عن طريق المراسلة بين الأسرة والمدرسة}

\section{خلاصة البحث}

يتناول البحث الميزات الأسرة والمدرسة ودورهما كعاملين رئيسيين في العمل التربوي والتعليمي. الهدف من هذا البحث هو دراسة وتفسير التمثيل وجودة التعاون عن طريق المراسلة

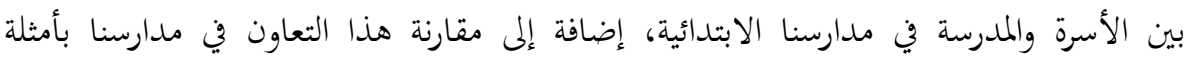
التعاون في ألمانيا وإيطاليا وكيف أن هذا التعاون يمكن تحسينه.

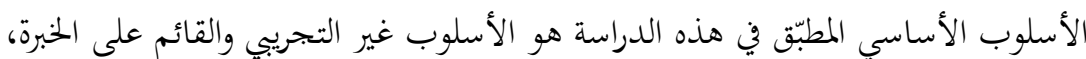
أسلوب سيروي (Servej) والعمل على الوثائق. الأداة الرئيسة في هذه الدراسة هو الاستبيان

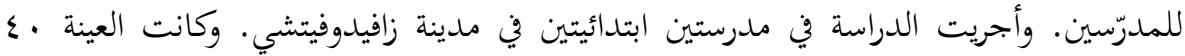
مدرّساً. يمكن استخلاص استنتاج واضح، بالمقارنة مع خبرة عالمية، أنه لدينا لم تستغل كافة الإمكانيات التي يقدّمها التعاون عن طريق المراسلة.

الكلمات الئيسة: التعاون عن طريق المراسلة، الوالدان، المدرسة، المدرّس المشرف، الوثائق المدرسيّة 